OBITUARY

\title{
Professor Andrew E. Czeizel, Hungary (April 3, 1935-August 10, 2015)
}

\author{
Julia Métneki, PhD \\ Hungarian Twin Registry
}

We are sad to announce the passing of Andrew E. Czeizel on August 10, 2015, at the age of 80, after a long-lasting illness.

Andrew E. Czeizel was a well-known physician and researcher in Hungary, although his scientific work was better recognized abroad. Dr Czeizel was a multi-talented, highly educated physician, scientist, geneticist, professor, public health administrator, writer, researcher of geniuses, family supporter, and much more. He was a pioneer in the health protection of fetuses and children, and assisted in the preservation of health, prevention of diseases, and congenital anomalies for everyone. His love of his work was legendary, and his dedication impressed everyone. Dr Czeizel authored many publications that appeared in English journals. They included 829 scientific publications, as well as authorship of 29 educational and 17 scientific books. The number of his citations has reached about 19,000; his hindex is 60 .

Dr Czeizel was well known for his discovery that periconceptional multivitamin supplementation, including vitamin B9 (folic acid), prevents or reduces the formation of more serious developmental disorders, especially neural tube defects like spina bifida. One of his key articles was published in the world's most prestigious medical journal, the New England Journal of Medicine, in 1994 and has been cited 2,750 times. He received the Kennedy Foundation International Award for this scientific achievement in 2000; his discovery prevented innumerable birth defects all around the world.

Dr Czeizel was the founder of the Budapest Twin Registry (BTR) in 1970, which offered a unique opportunity for scientific research in Hungary. He and his colleague, Julia Métneki, $\mathrm{PhD}$, demonstrated a causal connection between contraceptive pills containing high dose hormone used in the periconceptional period and the frequency of dizygotic twin births. The population-based Hungarian Congenital Abnormality Registry (HCAR) also offered a unique opportunity to study relationships between twinning and birth defects. The role of genetic factors was found to be negligible compared to the environmental (teratogenic and maternal) effects in a Hungarian sample of conjoined twins. Other research focused not only on genetic questions, but on risk factors in twin births. One of his studies assessed the retinopathy associated with premature births, a risk factor of multiple births. Additionally, his research evaluated the demographic and epidemiological characteristics of multiple births in Hungary.

In the 1980s, Dr Czeizel initiated a second, voluntary Adult Twin Registry, recruiting twins with newspaper advertisements and other media. The availability of these registries also offered possibilities for multiple international collaborations, such as one with the Hamburg Genetic Institute on alcohol consumption, sensitivity and metabolism, and melanoma prevention. There was also a collaboration with the Hamburg Dermatology Clinic, studying the nevi, and a study on adult lactose intolerance in collaboration with the Hannover Human Genetics Institute. Some of his twin studies resulted in new findings; for example, he was first in the world to identify the gene for lactose intolerance with the help of German-Hungarian academic collaborations. He also was first to report the 'side-effect' of periconceptional multivitamin supplementation containing folic acid, namely, the higher frequency of twin pregnancies cited above. His work was much appreciated, given its widespread national and international scientific recognition.

Dr Czeizel was a model of the modern scientist. Regarding his prominence, especially compared to Ignac Semmelweis (the gynecologist who discovered puerperal fever): 'the former was the savior of mothers; Dr Andrew E. Czeizel was the savior of fetuses'.

Andrew E. Czeizel, Medical Geneticist

Date and Place of Birth: April 3, 1935; Budapest, as a Hungarian citizen

Date and Place of Death: August 10, 2015; Budapest 


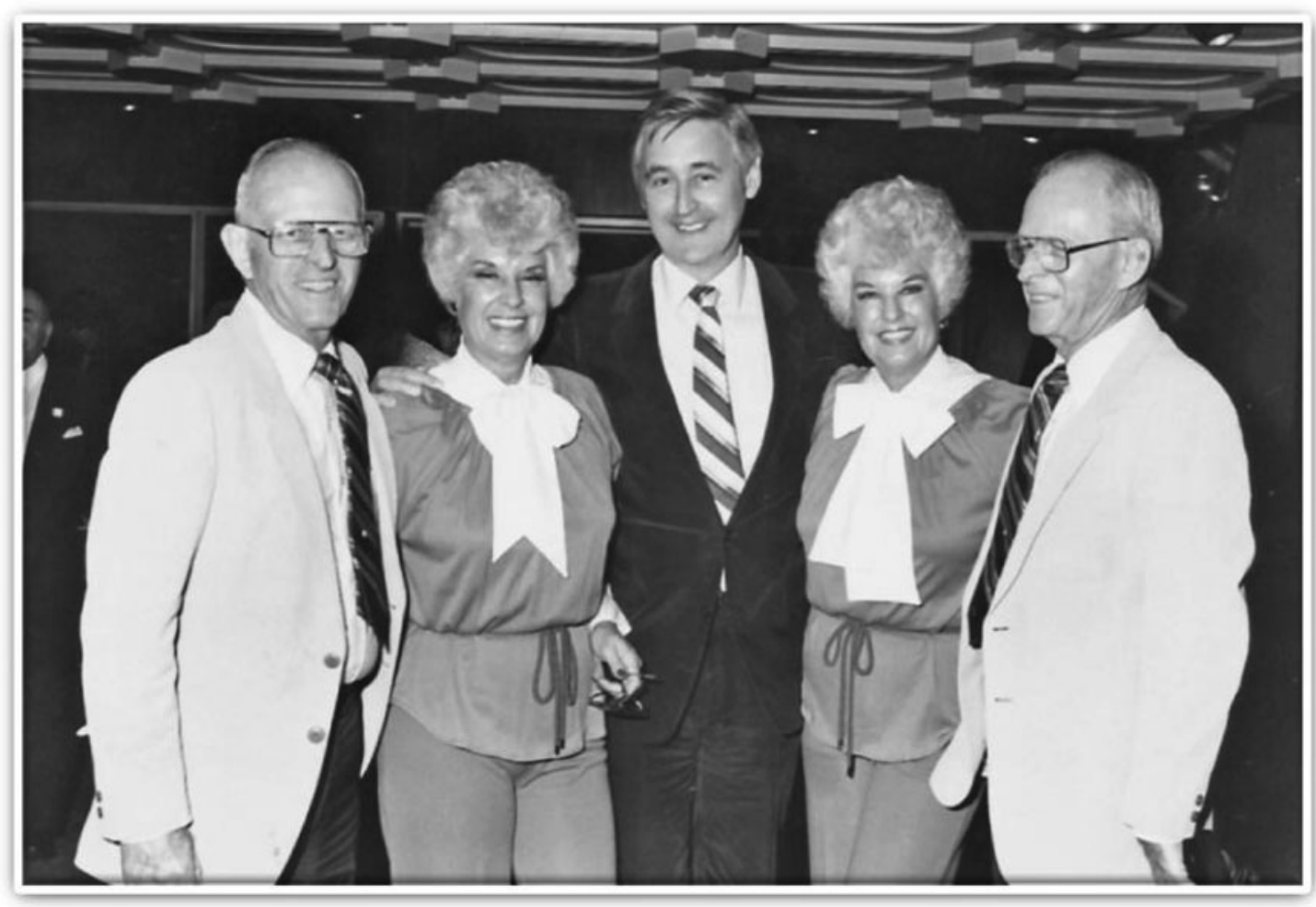

First Hungarian Twins Convention at the Hotel Hilton of Budapest in 1984. Dr Czeizel is in the middle with the leaders of the International Twin Association of the USA, Judy Stillwagon and Julie Kirk, and Lew and Lee Vaughn. Photograph by Imre Benkő.

\section{Education, Fellowship, and Scientific Degrees}

Faculty of General Medicine, Semmelweis University for Medical Sciences, Budapest (M.D.) (1953-1959), Specialty in General Laboratory (1963), PhD thesis: 'Investigations on the Pathogenesis of the Fetal Abnormalities' (1965), WHO Fellowship in Copenhagen/Glostrup, Denmark (1969) and in London and Edinburgh, UK (1971), Academic Doctorate of Medical Sciences Thesis: 'Etiological Studies of Common Isolated Congenital Abnormalities in Hungary' (1978), Specialty in Human Genetics (1978), Professor, Faculty of Genetics, Eötvös Loránd University of Sciences, Budapest (1996).

\section{Chronology of Employment}

Research fellow, National Institute of Hygiene (NIH) (19591973), Head of the newly established Laboratory of Human Genetics, NIH (1973-1988), Director of the WHO Collaborating Centre for the Community Control of Hereditary Diseases (1984-1998), Head of the newly established Department of Human Genetics and Teratology, NIH (19881998), Chief director of National Institute of Health Promotion (1996-1998), retirement (1998), Scientific director of the Foundation for the Community Control of Hereditary Diseases (1991-).

\section{International Professional Positions}

International Clearinghouse for Birth Defects Monitoring Systems (one of seven founders, Chairman in 1982), European Environmental Mutagen Society (President in 1988-1989), 8th International Congress of Human Genetics, Washington, D.C., 1991 (Vice-president), Hungarian Society for High Ability (President, 1994-2004, Emeritus president 2005-), Membership of Editorial Boards of American Journal of Medical Genetics, Journal of Medical Genetics, Human Genetics Congenital Anomalies, Balkan Journal of Medical Genetics.

\section{Research Areas}

Public Health and/or Community Genetic Activity

The establishment of the HCAR in 1970, several clusters were detected; for example, a 227-fold increase of Down syndrome in Rinyaszentkirály, 1989-1991 which resulted in the detection of aneugenic trichlorfon.

The establishment of the Hungarian Case-Control Surveillance of Congenital Abnormalities in 1980; at present, this data set contains the highest number of cases and controls with prospective medically recorded exposures (drugs and maternal diseases) in the world and was used in several international collaborations. 
The establishment of the Budapest Monitoring System of Self-poisoned Pregnant Women, in 1980. Pregnant women who attempt suicide during pregnancy represent a unique 'disaster epidemiological model' for the study of teratogenic and mutagenic effect of chemicals.

Ad hoc epidemiological studies were organized based on the active ascertainment of all possible cases with specified congenital abnormalities; these results were published in three English monographs.

The first modern population-genetic study was performed in the Hungarian population, based on 26 genetic markers, due to the collaboration of the German and Hungarian Academy of Sciences, and the results were published in two English books.

\section{Clinical Activity}

The Genetic Counseling Clinic was founded in NIH, in 1973, and the so-called information guided counseling method was introduced in Hungary as an intermediate step between the previous directive and expected non-directive counseling, because the latter was not accepted by Hungarian clients.

Periconceptional care/service was introduced in 1984 at the request of WHO, and a national network was established in Hungary, 1989, the first in the world. This periconceptional care provided an opportunity to organize a randomized controlled trial to show that a multivitamin containing a physiological dose of folic acid $(0.8 \mathrm{mg})$ was effective for the reduction of first occurrence of neural-tube defects, in addition to cardiovascular malformations, urinary tract defects, and congenital limb deficiencies.

\section{Twin Registry and Twin Research}

Establishment of the BTR in 1970-1995, and a national volunteer Adult Twin Registry (1983-). Twin studies in national and in international collaborations were performed with the some new findings; for example, detection of the hereditary model of lactose intolerance, and the higher frequency of twin pregnancies with periconceptional multivitamin supplementation containing folic acid.

\section{Honors and Other Special Scientific Recognitions}

Markusovszky Award (1970, 1973), Award of the Hungarian Academy of Sciences $(1976,1979)$, Award for Youth (1986), Eminent Medical Doctor (1989), Grand Cross of Hungarian Republic (1995), Award for Children (1996), Medal of Health, United Arab Emirates (1996), Kennedy Award, US (2000), Certificate of US National Council on Folic Acid (2002), Grand Star Cross of Hungarian Republic (2005), Meinhard von Pfaundler Prize for Paediatric Prevention (German Child Health Foundation) (2010), Award for Nation (2011), Award of Radnóti (2012), Semmelweis Award (2014).

\section{Dr Czeizel's Publications on Twin Studies}

Agarwal, D. P., Goedde, H. W., Benkmann, H. G., \& Métneki, J. (1997). Twin studies of alcohol metabolism and responses. In D. P. Agarwal, B. Buda, A. E. Czeizel, \& H. W. Goedde (Eds.), Alcohol consumption and alcoholism in Hungary. Ethnocultural, epidemiological and biomedical aspects (pp. 138141). Budapest: Akadémiai Press.

Czeizel, E., Pazonyi, I., Métneki, J., Tomka, M. (1979). The first five years of the Budapest Twin Register. Acta Geneticae Medicae et Gemellologiae, 28, 73-76.

Czeizel, A.E., Métneki, J., Dudás, I. (1994). Higher rate of multiple birth after periconceptional multivitamin supplementation. New England Journal of Medicine, 23, 1687-1688.

Czeizel, A. E., Métneki, J., \& Dudás, I. (1994). The higher rate of multiple births after periconceptional multivitamin supplementation: An analysis of causes. Acta Geneticae Medicae et Gemellologiae, 43, 175-184.

Czeizel, A. E., Dudás, I., \& Métneki, J. (1994). Pregnancy outcomes in a randomized controlled trial of periconceptional multivitamin supplementation. Archives of Gynecology and Obstetrics, 255, 131-139.

Czeizel, A. E, Métneki, J., \& Dudás, I. (1996). The effect of periconceptional multivitamin supplementation on fertility. International Journal for Vitamin and Nutrition Research, $66,55-58$.

Flatz, G., Czeizel, A., Métneki, J., Flatz, S. D., Kühnau, W., \& Jahn, D. (1985). Pulmonary hydrogen and methane excretion following ingestion of an unabsorbable carbohydrate: A study of twins. Journal of Pediatric Gastroenterology and Nutrition, 4, 936-941.

Hundrieser, J., Nürnberg, P., Czeizel, A. E., Métneki, J., Rothganger, S., Zischler, H., \& Epplen, J. T. (1992). Characterization of hypervariable locus-specific probes derived from a (CAC)5(GTG)5 multilocus fingerprint in various Eurasian populations. Human Genetics, 90, 27-33.

Láng, E., Szilágyi, N., Métneki, J., Czeizel, A., \& Ádám, G. (1990). Genetic and environmental control of cardiac reaction in humans: A study based on impedance cardiography and spectral analysis of heart period. In Proceedings of the 5th International Congress of Psychophysiology (p. 174). Budapest.

Métneki, J., \& Czeizel, A. (1980). The twin occurrence after the use of contraceptive pills. Acta Morphologica Academiae Scientiarum Hungaricae, 1-2, 216-217.

Métneki, J., \& Czeizel, E. (1980). Contraceptive pills and twins. Acta Geneticae Medicae et Gemellologiae, 29, 233-236.

Métneki, J., \& Czeizel, A. (1983). Twinning rates in Hungary. Lancet, 1, 934-935.

Métneki, J., Czeizel, A., Flatz, S. D., \& Flatz, G. (1984). A study of lactose absorption capacity in twins. Human Genetics, 67, 296-300.

Métneki, J., \& Czeizel, E. (1986). The multiple births [in Hungarian]. In P. Véghelyi \& O. Kerpel-Fronius (Eds.), The newborn [in Hungarian], pp. 551-569. Budapest: Akadémia Press. 
Métneki, J., \& Czeizel, A. (1987). Griseofulvin teratology. Lancet, 1, 1042.

Métneki, J., \& Czeizel, A. (1989). Conjoined twins in Hungary, 1970-1976. Acta Geneticae Medicae et Gemellologiae, 38, 285-299.

Métneki, J., Czeizel, E., \& Vitéz, M. (1991). Ikrek gyakorisága és kóreredeti vizsgálata az iskoláskorú súlyos látási fogyatékosok között. Occurrence and etiological study of twins among severe schooling age children with visual deficient [in Hungarian]. Szemészet, 1, 33-37.
Métneki, J., Pazonyi, I., \& Czeizel, A. (1992). Unidentified multiple congenital abnormalities in twins. A populationbased Hungarian study. Acta Paediatrica Hungarica, $32,3$.

Métneki, J., Czeizel, A. E., \& Evans, J. A. (1996). Congenital limb reduction defects in twins. European Journal of Pediatrics, 155, 483-490.

Métneki, J., Tárnoki, A. D., Tárnoki, D. L., Littvay, L., \& Czeizel, A. (2011). Psychosexual study of communist era Hungarian twins. Twin Research and Human Genetics, 14, 144-149. 